\title{
不織布（その8）
}

\section{三 浦 義 $人$}

\section{第 1 章 緒論}

1.1 定義と歴史

1.2 特徴

1.3 製品上の分類

1.4 不織布事情

第 2 章 原料繊維

2.1 一般的性質

2.2 乾式用繊維

2.3 湿式用繊維

第 3 章 接着剤

3.1 熱接着繊維

\section{2 乾式用接着剂}

3.3 湿式用接着剂

第 4 章 ウエブの形式

4.1 混開繊

4.2 カーディング

4.3 ランダムウェビング

4.4 スパンボンド方式

4.5 たて, よこ積層法

4.6 抄紙法

4.7 .ウェブの厚さと均斉度の測定法

第 5 章 ウエブの接着
$5: 1$ ケミカルボンドとサーマルボンド

5.2 ニードルパンチ

5.3 ウォータージェットパンチ

5.4 ステッチボンド

第. 6 章 仕上加工

6.1 乾燥, 熱処理

6.2 コンポジット

\section{第 7 章 試験法と規格}

\section{1 乾式不織布芯地}

7.2 接着芯地

\section{3 靴甲用人工皮革}

（太字は本号掲載分）

\section{第 7章 試験法と規格}

不織布の試験法に関し，日本工業規格が定まって いる乾式不織布芯地 (L 1085 1969), 接着芯地 (L $1086 \sim 1975)$, 又, 靴甲用人工皮革 (K $650 \sim 1971)$ につき述べる ${ }^{1,2)}$. 敷物試験方法（L 1021）之業界の 自主規格である医療用不織布と NPC (ニードルパ ンチカーペット）マークカーペットに関する試験方 法は省略する.

\section{1 乾式不織布芯地試験方法}

（1） 適用範囲

この規格は乾式不織布芯地の試験方法について規 定する.

（2）用語の意味

1) 試験室の標準状態：JIS Z 8703（試験場所の 標準状態) の標準温湿度状態 2 類 (温度 $20 \pm 2{ }^{\circ} \mathrm{C}$, 相対湿度 $65 \pm 2 \%$ )とする. ただし, 上記の状態に 保てない場合は試験時の温湿度を付記する.
2 ) 試料の標準状態：試料を標準状態に放置し水 分平衡に至らさせた状態をいう。

3 ) 水分平衡：予備乾燥 (温度 $40 \pm 5{ }^{\circ} \mathrm{C}$ ) を行っ た後, 試料を標準状態の試験室に放置して恒量とな った状態をいう。

4) 絶乾状態及び絶乾重量：試料を温度 $105 \pm$ $2{ }^{\circ} \mathrm{C}$ の乾燥機中に放置して恒量となった状態を絶 乾状態といい, このときの重さを絶乾重量という.

5 ) 恒量: 水分平衡のときは 1 時間以上, 絶乾状 態の時は15分間以上の間隔で重さをはかり, その前 後の重量差があとの重さの $0.1 \%$ 以内となった状態 をいう.

\section{(2) 試料の採取及び準備}

試料は芯地を代表するようにランダムに採取する むのとする，温湿度が影響する試験に供する試料は 試験前に予備乾燥を行って, 標準状態の試験室の所 定の場所又は装置に放置し標準状態にする.

(4) 試験項目

(1)厚さ，(2)重さ，(3)水分率，(4)引っ張り強さ及び 
伸び伸，(5)引き裂き強さ，(6)防しわ率，(7)剛軟度, (8)収縮率, (9)乾燥速度, (10)耐光堅牢度, (11)ドライク リーニング強さ，(12)アイロンの許容温度，(13)繊維混 用率

\section{（5）試験方法}

1) 厚さ：試料の異なる 5 か所について, 原則と して厚さ測定機を用いて $20 \mathrm{~g} / \mathrm{cm}^{2}$ の荷重のもとで 一定時間（加圧下で厚さが一定になるまでの時間で 普通 $10 \mathrm{sec}$ が望ましい）放置して厚さ（mm）をは かり, その平均で表す (小数点以下 2 けたまで). た だし，試験条件を付記する，厚さ測定機のプレッサ ーフートは $2 \mathrm{~cm}^{2}$ のあのを使用するのを原則とする が，これによれないときは条件を付記する.

2) 重さ： $20 \mathrm{~cm} \times 20 \mathrm{~cm}$ の試験片を 3 枚採取 し，それぞれ水分平衡に至らせた状態の重さ $(\mathrm{g})$ を はかり, その平均値を単位面積当たり $\left(\mathrm{g} / \mathrm{m}^{2}\right)$ で表 す（小数点以下 1 けたまで).

3 ）水分率: $20 \mathrm{~cm} \times 20 \mathrm{~cm}$ の試験片を 2 枚採取 し乾燥前の重さと絶乾重量をはかり, 次の式で水分 率（\%）を算出し，その平均値で表す（小数点以下 1 けたまで).

$$
\text { 水分率 }(\%)=\frac{W-W_{1}}{W_{1}} \times 100
$$

ここに $W$ は乾燥前の重さ $(\mathrm{g}), W_{1}$ 絶乾重量 $(\mathrm{g})$ [参考] 含水率 $(\%)=\frac{W-W_{1}}{W} \times 100$

4 ）引っ張り強さ及び伸び率：試料はたてとよこ 方向に 5 枚ずつ採取し JIS L 1068 (織物の引っ張り 試験方法）に準じ，つかみ間隔を $10 \mathrm{~cm}$, 引っ張り 速度は毎分 $30 \pm 2 \mathrm{~cm}$ として切断強さ $(\mathrm{kg})$ 及び伸 び率（\%）をはかり, その平均值で表す（引っ張り 強さは小数点以下 1 けたまで, 伸び率は整数位ま で).ただし，上記の条件と異なる時は試験条件を付 記する.

\section{（5）引き裂き強さ}

$\mathrm{A}_{1}$ 法（シングルタング法）： $5 \mathrm{~cm} \times 25 \mathrm{~cm}$ の試 験片をたて, よこ方向にそれぞれ 5 枚採取し, 短片 の中央に辺と直角に $10 \mathrm{~cm}$ の切れ目を入れて 2 枚 の舌を作り, 幅 $5 \mathrm{~cm}$ 以上のつかみを有する引っ張 り試験機を用い, つかみ間隔を $10 \mathrm{~cm}$ として各舌片 をつかみと直角に挟み, 引っ張り速度を毎分 $30 \pm$ $5 \mathrm{~cm}$ として引き裂くときに示す最大荷重 $(\mathrm{kg})$ を はかり，たて，よこ方向それぞれ平均値で表す（小 数点以下 1 けたまで).

$\mathrm{A}_{2}$ 法（ダブルタング法）：15 cm× $18 \mathrm{~cm}$ の試験

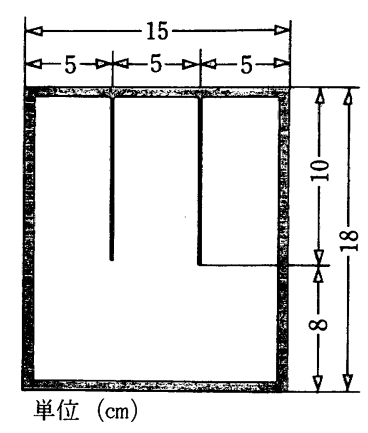

図 $7 \cdot 1$ ダブルタング法の試験片

片をたて,よこ方向にそれぞれ 5 枚採取し図 $7 \cdot 1$ のように短片を 3 等分する位置に辺之直角に $10 \mathrm{~cm}$ の切れ目を入れ, 幅 $15 \mathrm{~cm}$ 以上のつかみを有する引 つ張り試験機を用い, 試験片のつかみ間隔を $10 \mathrm{~cm}$ として一方のうかみに試験片の中央舌片を他方のつ かみに外側舌片をつかみと直角に挟む. 引っ張り速 度は毎分 $30 \pm 5 \mathrm{~cm}$ として $2.5 \mathrm{~cm}$ の長さを残して 引き裂き, この時示す最大荷重 $(\mathrm{kg})$ をはかりたて, よこ方向それぞれの平均値で表す（小数点以下 1 け たまで).

B 法 (トラペゾイド法)： $5 \mathrm{~cm} \times 25 \mathrm{~cm}$ の試験片 をたて,よこ方向にそれぞれ 5 枚採取し, 図 $7 \cdot 2$ に 示すように等脚台形のマークを付け, このマークの 短片の中央と直角に $1 \mathrm{~cm}$ の切れ目を入れ, 幅 $5 \mathrm{~cm}$

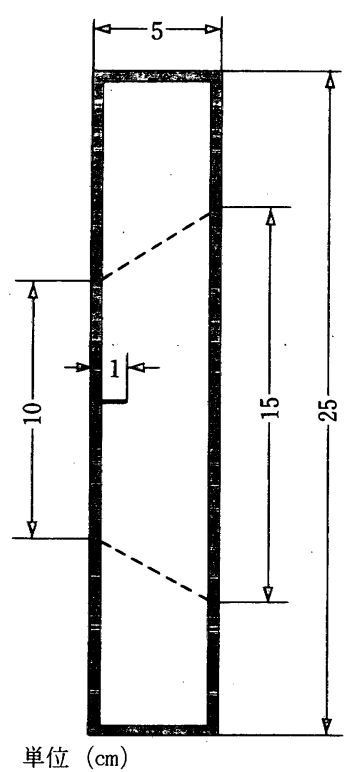

図 $7 \cdot 2$ トラペゾイド法の試験片 
以上のつかみを有する引っ張り試験機を用い, つか み間隔を $10 \mathrm{~cm}$ として台形の短辺を張り長辺はゆ るめて, 引っ張り速度を毎分 $30 \pm 5 \mathrm{~cm}$ として引き 裂く時に示す最大荷重 $(\mathrm{kg})$ をはかり，たて，よこ 方向それぞれの平均値で表す（小数点以下 1 けたま で).

C 法（ベンジュラム法）：6.5 cm × $10 \mathrm{~cm}$ の試験 片をたて，よこ方向にそれぞれ 5 枚採取し，エレメ ンドルフ引き裂き試験機を用い試験片の両つかみの 中央で長辺のほぼ中央に, 辺と直角に鋭利な刃物に よって $2 \mathrm{~cm}$ の切れ目を入れ, 残り $4.5 \mathrm{~cm}$ が引き裂 かれた時に示す最大荷重 $(\mathrm{kg})$ をはかり，たて，よ こ方向をそれぞれの平均值で表す（小数点以下 2 け たまで).

\section{(6) 防しわ率}

A 法（針金法）：1 cm $\times 4 \mathrm{~cm}$ の試験片をたて, よこ方向にそれぞれ 5 枚採取し，たて，よこともに $1 \mathrm{~cm} \times 2 \mathrm{~cm}$ の大きさになるように長辺を直角に 2 つ折りとする。これをガラス板の間に挟み $500 \mathrm{~g}$ の荷重を加え 5 分間放置したのち除重し, 図 $7 \cdot 3$ のように試験片の一熱の中央を注意深くピンセット で挟み, 直ちに緊張した径 $0.51 \mathrm{~mm}$ の針金（SWG No. 25 に相当）上に折り目の部分をかけるか, 又は 同等の性能をむつ試験機にかけて 5 分間放置後, 布 の開角度を図 $7 \cdot 4$ の位置ではかる.

B 法（モンサント法）：1 cm $\times 4 \mathrm{~cm}$ の試験法を たて, よこ方向にそれぞれ 5 枚採取し, 図 $7 \cdot 5$ に示 すモンサント型試験機の試験片ばさみに挟み, 上側 の短いプレートから出ている部分を折り返してプラ スチック製の押さえで挟み， $500 \mathrm{~g}$ の荷重を加えて 5 分放置した後除重し, 試験片ばさみを注意しなが ら試験機の試験片ばさみ支持架にそのまま差し込 む. 試験片の懸垂している部分は絶えず試験機の中

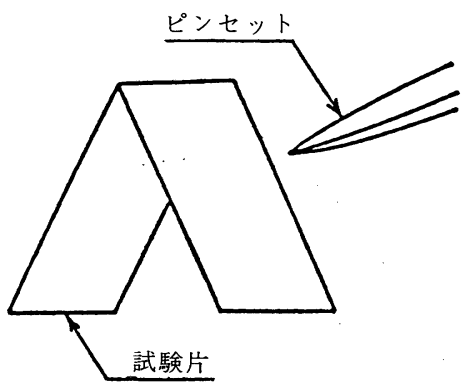

図 $7 \cdot 3$ 針金法の試料

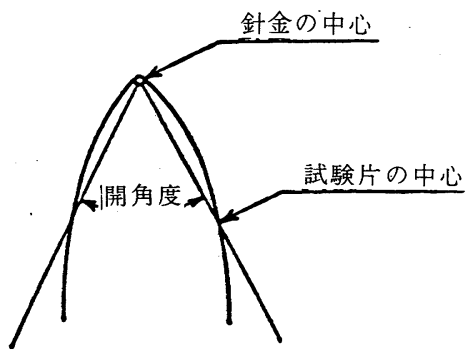

図 $7 \cdot 4$ 針金法

心の重線に一致させるように試験機の回転板を回転 し， 5 分後に試験片の開角度をはかる.

・防しわ率算出方法：前述の試験方法のいずれか によって試験片の開角度をはかり次の式で防しわ率 を算出してたて，よこ方向それぞれの平均值で表わ す(整数位まで).

防しわ $(\%)=\frac{\alpha}{180} \times 100 \quad \alpha$ は開角度

\section{(7) 剛軟度}

$\mathrm{A}$ 法 $\left(45^{\circ}\right.$ カンチレバー法) $: 2 \mathrm{~cm} \times 15 \mathrm{~cm}$ の試 験片をたて, よこ方向にそれぞれ 5 枚採取し, 図 7 . 6 に示すカンチレバー型試験装置で一端が $45^{\circ}$ の

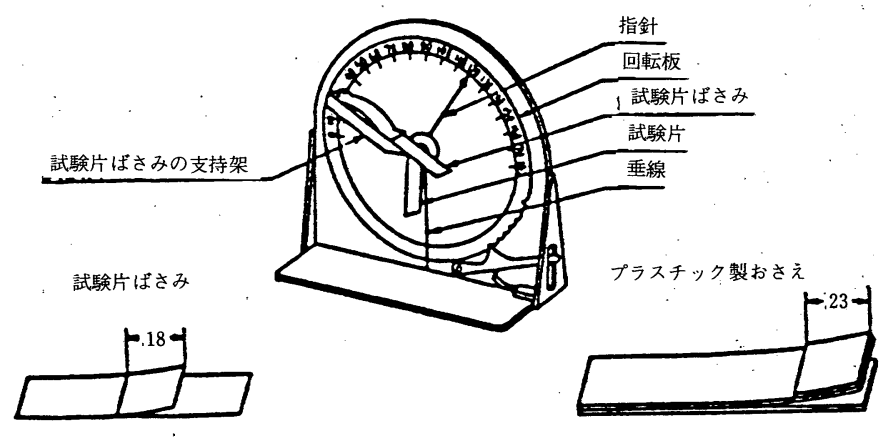

図 $7 \cdot 5$ モンサント法（単位 $\mathrm{mm}$ ) 


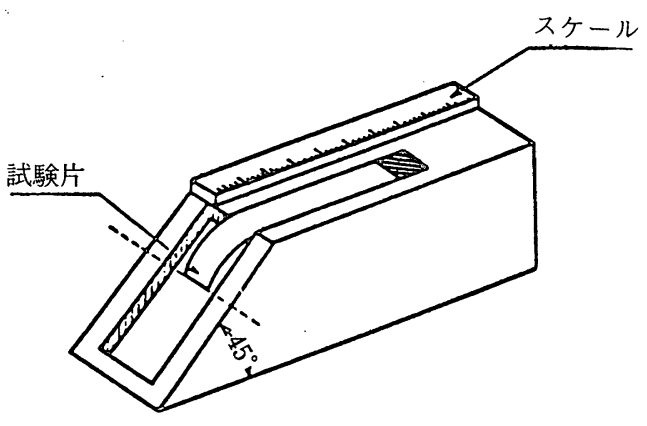

図 $7 \cdot 6$ カンチレバー法

針面をむつ表面の滑らかな水平台の上に，短片をス ケールの基線に合わせて置いた後, 適当な方法で試 験片を斜面の方向にゆるやかに滑らせて, 試験片の 一端の中央が斜面と接した時, 試験片の他端の位置 をスケールによって読む. 剛軟度は試験片の押す出 された長さ (mm) で示され, それぞれの 5 枚の表 裏をはかりたて, よこ方向の平均值で表す（整数位 まで).

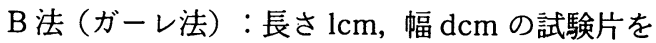
たて，よこそれぞれ 5 枚採取し図 $7 \cdot 7,7 \cdot 8$ に示 すようなガーレ式試験器を用い試験片をチャックに 取り付け, 可動アーム A 上の目盛 $1 / 2.54$ に合わせて チャックを固定する.

次に振子 B の支点より下部の荷重取り付け孔 $\mathrm{a}$, $\mathrm{b}, \mathrm{c}$ に適当な荷重 $W_{a}(\mathrm{~g}), W_{b}(\mathrm{~g}), W_{c}(\mathrm{~g})$ をか けて可動アームを定速回転させ, 試験片が振子 B か ら離れる時の目盛 $R G$ を読み, 次の式から剛軟度を 求めたて, よこの各の 5 枚の表裏について平均値で 表す（小数点以下 1 けたまで).

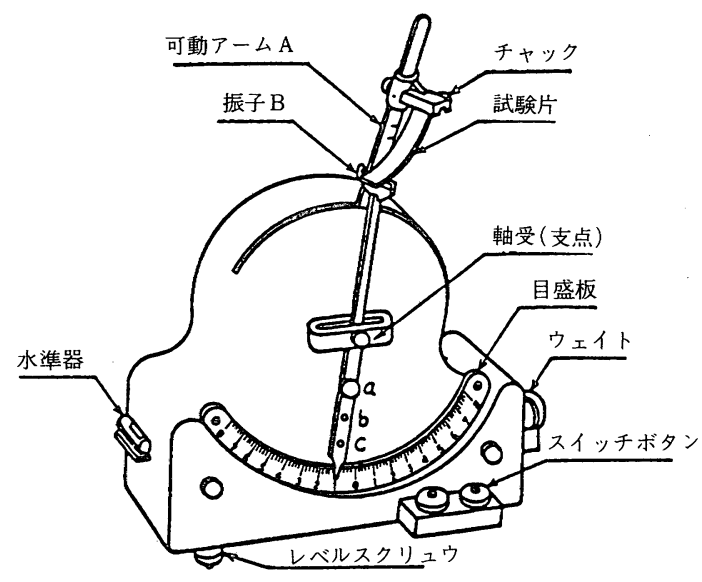

図 $7 \cdot 7$ ガーレ法

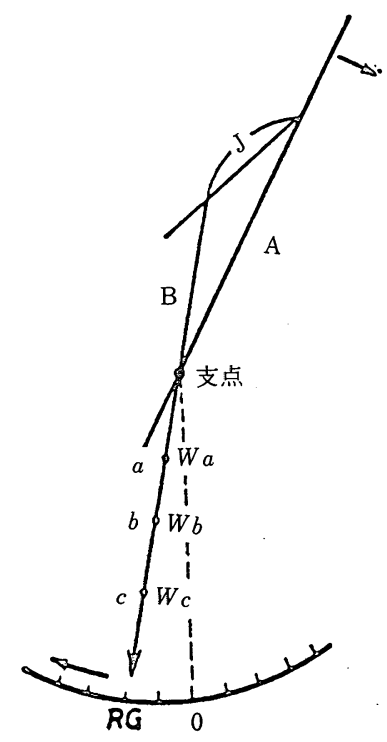

図 $7 \cdot 8$ ガーレ法の係数

剛軟度 $(\mathrm{mm})=R G \times\left(a W_{a}+b W_{b}+c W_{c}\right) \times \frac{l^{2}}{d}$ $\times 0.306$

ここに a, b, c は荷重取り付け孔と支点間の距離 $(\mathrm{cm})$

8 ）収縮率：JIS L 1042 （織物の収縮率試験方法） の A 法 (常温水浸漬法) 及び D 法 (石䶧液法) によ る.

9）乾燥速度：JIS L 1079 (化学繊維織物試験方 法）の $5 \cdot 26 \cdot 1 \mathrm{~B}$ 法による.

10）耐光堅牢度：JIS L 1044 （染色物及び染料の 耐光堅军度試験方法）及び JIS L 0841（日光に対す る染色堅审度試験方法）による.

11）ドライクリーニング強さ：10 $\mathrm{cm} \times 10 \mathrm{~cm}$ の 試片を 2 枚採取し図 $7 \cdot 9$ に示すような振とう式試 験機 ( $7 \mathrm{~cm}$ の距離を $60 \mathrm{rpm}$ で往復動する) 用い, $1 l$ の容器にトリクレン $400 \mathrm{ml}$ を入れ, 次いで試験 片を入れて10分間操作した後脱液し常温で乾燥す る. 乾燥した試験片を試験前と比較して次の評価を する.

○ $\mathrm{a}$ : 重量変化率 $\left(W-W_{1}\right) / W(\%) W$ は試験前 の重さ $(\mathrm{g}), W_{1}$ は試験後の重さ $\left.(\mathrm{g})\right)$

- $\mathrm{b}$ : 形態の変化 (A 級は変化なし, B 級は変化 の目立つもの, C 級は変化の著しいもの, JIS L 0801 の10による)

○ c : 色相の変化

12）アイロンの許容温度 : 任意の大きさの試験片 


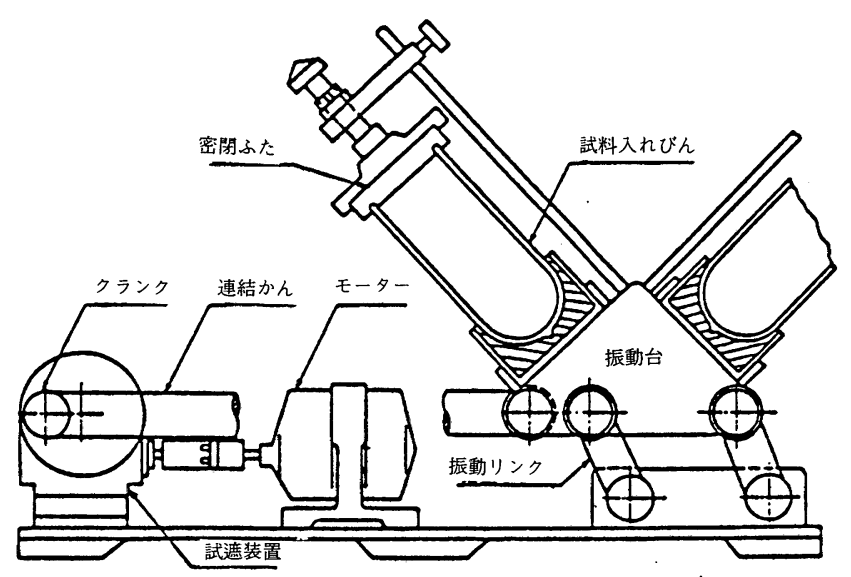

図 $7 \cdot 9$ 振とう式試験法

を採取しアイロン台上に自然の状態に置いた後, 重 さ約 $2.27 \mathrm{~kg}$ の電気アイロン（自動温度調節装置付 き, $1 \mathrm{~cm}^{2}$ 当たり約 $12.5 \mathrm{~kg}$ の自重）で約 $20 \mathrm{sec}$ に $10 \mathrm{~cm}$ の距離を 10 往復という条件で, アイロンの自 重下でアイロンがけを行って試験片の表面の変化を 観察する. アイロンの温度の確認には表面温度計を 用い加熱された電気アイロンの底部中央に当てては かる. アイロンの温度は $80^{\circ} \mathrm{C}$ から $180^{\circ} \mathrm{C}$ まで $10^{\circ} \mathrm{C}$ 刻みに測定して試験を行い, 試験片の表面に初めて 変化が現われる温度の前の温度をその試料のアイロ ンの許容温度とする。

(3) 繊維混用率試験

試料の調整：約 $10 \mathrm{~cm} \times 10 \mathrm{~cm}$ 又は約 $1 \mathrm{~g}$ の試験 片を 5 枚採取し有機溶剤 (塩化メチレン, エーテル, 酢酸等）で十分常温処理して，接着剂を溶解又は膨 潤させた後試験片をできるだけ繊維状に解体する. 次にこれを更に前述の溶剂で処理してから $105 \pm$ $2{ }^{\circ} \mathrm{C}$ の乾燥機中で乾燥する.

試験法：前項の試料について JIS L 1030 (繊維漉 用率試験方法）の溶解法による.

[参考] 洗濯試験方法

$25 \mathrm{~cm} \times 25 \mathrm{~cm}$ の試験片等を10枚採取し試験片を それぞれ 5 個の洗濯袋（100\%ポリエステルの10

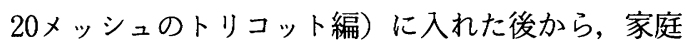
用電気洗濯機に $40 \pm 3{ }^{\circ} \mathrm{C}$ の0.5\% マルセル石針溶 液を $20 l$ 以上入れ, 次いで試験片の入った石鹷袋 5 個を入れて毎分500回の回転速度で15分操作した後, 水洗脱水し, 常温で乾燥する. 乾燥した試験片を試 験前と比較して重量変化, 形態変化と色相変化の評 価をする. ソクスレー抽出器で 2 時間還流抽出を行
う. 次いで乾燥せずに塩化メチレンに常温浸漬し接 着剂を十分に溶解又は膨潤させる. 有機溶剤を含浸 した状態で手操作により試験片を繊維状に解体す る. 次に再びソススレー抽出器で塩化メチレンによ って還流抽出を行った後, 脱液乾燥する.なお,こ の試験に使用したウェブはレーヨン $40 \%$, ポリエス テル $60 \%$ に計画されたあのである. 混用率試験結果 を表 $7 \cdot 1$ に示す.

\section{2 接着芯地試験方法}

\section{（1）適用範囲}

この規格は接着芯地（熱可塑性の接着剂があらか じめ付与されている織物, 編物及び不織布製の芯 地）の試験方法について規定する.

\section{（2）用語の意味}

$7 \cdot 1$ の 2 と同じであるから省略

\section{（3）試料の採取及び準備}

L 1085 之同様であるが, 複合試験片の作り方は適 当な性能を持つ接着用機器（フラットベッドプレス 機, ローラープレス機, 連続式プレス機, アイロン 等)を用いてあらかじめ設定した接着条件（接着用 機の熱が接着剂表面に十分に伝わり，軟化した接着 剂が均等に浸透し, 均一な接着力を得るのに適した 温度 $\left({ }^{\circ} \mathrm{C}\right)$, 圧力 $\left(\mathrm{kgf} / \mathrm{cm}^{2}\right)\{\mathrm{kPa}\}$, 時間 $(\mathrm{sec})$, スチーミングの時間 (sec) 等) のあとで, 試料と被 接着布（試料の採取方法に準じて採取, 準備したも の）とを接着した後, 標準状態の試験室に少なくと す24時間以上放置したものから，個々の試験方法に 規定する大きさのものを，規定する枚数採取する. この場合, 接着用機器及び接着条件を付記する. 
表 $7 \cdot 1$ 不織布芯地の混用率試験結果

\begin{tabular}{|c|c|c|c|c|}
\hline 項目 & 前処理後の絶乾 & 溶解処理後の絶 & 溶解した繊維の & 溶解繊維の混用 \\
\hline 試験回数 & 重量 ${ }^{(5)} \quad$ （g） & 乾重量 ${ }^{(6)}$ （g） & 重量 ${ }^{(7)} \quad$ (g) & 率 ${ }^{(8)} \quad(\%)$ \\
\hline 1 & 0.5869 & 0.3925 & 0.1944 & 33.1 \\
\hline 2 & 0.6367 & 0.4160 & 0.2207 & 34.7 \\
\hline 3 & 0.5650 & 0.3775 & 0.1875 & 33.1 \\
\hline 4 & 0.5660 & 0.3465 & 0.2195 & 38.7 \\
\hline 5 & 0.5681 & 0.3920 & 0.1761 & 31.0 \\
\hline 6 & 0.5730 & 0.3800 & 0.1930 & 33.7 \\
\hline 7 & 0.5510 & 0.3600 & 0.1910 & 34.6 \\
\hline 8 & 0.5859 & 0.3721 & 0.2138 & 36.5 \\
\hline 9 & 0.5921 & 0.3837 & 0.2084 & 35.2 \\
\hline 10 & 0.5948 & 0.3895 & 0.2052 & 34.5 \\
\hline 平均值 & & & & 35.32 \\
\hline
\end{tabular}

注（5）(1)〜(5)の手順で処理した後の試験片の絶乾重量.

（6）JIS L 1030 (繊維混用率試験方法）の 8.1.7 によって処理したのちの絶乾重量

（7）溶解した瀻維（レーヨン）の重量.

（8）溶解した緘維（レーヨン）の混用率.

\section{(4) 試験項目}

試験方法に記してあるから省略

(5) 試験方法

1）幅：芯地を平らかな台の上に置き，不自然な しわや張力を除き，異なる 5 箇所以上について両端 にある不完全な部分を除いた幅 $(\mathrm{cm})$ を測定し，そ の平均值を小数点以下まで求める.なお全幅を測定 した場合は，その旨付記する。

2 ）長さ：芯地を平らかな台の上に置き，不自然 なしわや張力を除いて, 測長器で端末にある不完全 な部分を除いた長さ（m）を，小数点以下 1 けたま で測定する．なお全長を測定した場合はその旨を付 記する，又，ロール巻きの場合は検尺機で全長を測 定してあよい.

3 ）質量，4）厚さ，5）密度：L 1085 と同じ密 度省略

6）ドット密度：試料の 5 箇所以上における適当 な区域 $(1 \mathrm{~cm} \times 1 \mathrm{~cm}, 2.54 \mathrm{~cm} \times 2.54 \mathrm{~cm}$ 等 $)$ のド ット数（ドットとは接着樹脂の一定量が豆状に付与 されたもの）を数え，その平均値を整数位まで求め る.

7 ) 水分率：L 1085，8）布目曲がり省略

9 ）引っ張り強さ及び伸び率：JIS L 1018 （メリ リス生地試験法の $6 \cdot 15$ 又は JIS L 1096 （一般織物 試験方法) の $6 \cdot 12$ による.

10）引き裂き強さ：A 法 (ペンジュラ.ム法), B 法 （シングルタング法）による.
11）破裂強さ：試料から約 $15 \mathrm{~cm} \times 15 \mathrm{~cm}$ の試験 片 5 枚を採取し，ミューレン型破裂強さ試験機を用 い，しわ及びたるみを生じないように均一な張力を 加えてクランプでつつみ，加えられた圧力によりゴ 么隔膜が試験片を破る強さ $\left(\mathrm{kgf} / \mathrm{cm}^{2}\right)\left\{\mathrm{N} / \mathrm{cm}^{2}\right\}$ 及 びクランプを除いたときのゴム膜の強さ（kgf/ $\left.\mathrm{cm}^{2}\right)\left\{\mathrm{N} / \mathrm{cm}^{2}\right\}$ を測定し，次式から破裂強さ（kgf/ $\left.\mathrm{cm}^{2}\right)\left\{\mathrm{N} / \mathrm{cm}^{2}\right\}$ を算出し，5回の平均値を小数点以 下 1 けたまで求める. クランプの直径は $3.05 \pm 0.3$ $\mathrm{cm}$, 圧力を加えるための油の増加割合いは原則と して 1 万回当たり $98 \pm 4 \mathrm{ml}$ と定められている. な お試験機のゴム隔膜は鉱物質の充てん剂を含まない 厚さ $0.84 〜 0.89 \mathrm{~mm}$ の純ム質であること，課験 機の検定は標準アルミはく（厚さ $50 \mu \mathrm{m}$, 比重 2.71 , 純度 $99.6 \%$, 破裂強さ $3.73 \mathrm{kgf} / \mathrm{cm}^{2} \quad\left\{37.3 \mathrm{~N} / \mathrm{cm}^{2}\right\}$ を用いて補正を行う。

破裂強さ $\left(\mathrm{kgf} / \mathrm{cm}^{2}\right)\left\{\mathrm{N} / \mathrm{cm}^{2}\right\}=\mathrm{A}-\mathrm{B}$

$\mathrm{A}$ ：ゴム隔膜が試験片を突き破る強さ

B：クランプを除いた時のゴム隔膜の強さ

図7·10はミューレン型破裂試験機の構造である.

12）剛軟性：L 1085 の $45^{\circ}$ カンチレバー法とドレ ープ係数法がある. 直径 $25.4 \mathrm{~cm}$ の円形試験片 5 枚 を採取し，各試験片の中心に直径約 $1 \mathrm{~cm}$ の孔をあ け，次に試験片の測定面を上にして図 $7 \cdot 11$ に示す ドレープテスターの試験台（直径 $12.7 \mathrm{~cm}$ ）上に置 き, 試料台を 3 回上下に振動させてから 1 分間放置 後のドレープ形状面積を測定し, 次式からドレープ 


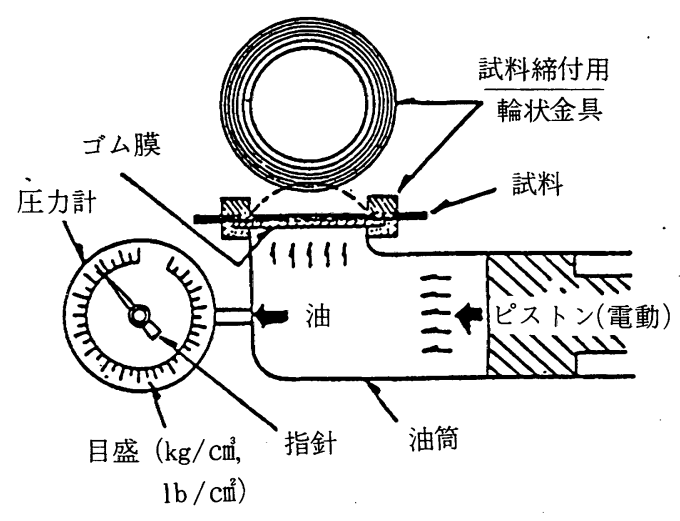

困 $7 \cdot 10$ ミューレン型破裂試験法
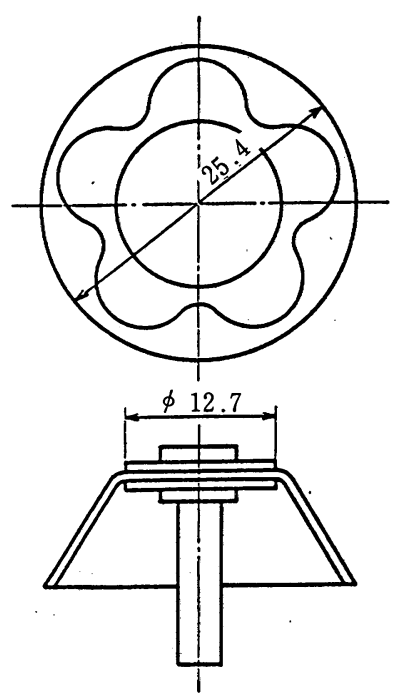

図 $7 \cdot 11$ ドレープテスター（単位 $\mathrm{cm}$ )

係数を算出し，それぞれ表裏（接着剤が付与されて いない面を表, 付与されている面を裏にする）につ いて, 平均值を小数点以下 3 けたまで求める.

$$
\text { ドレープ係数 }=\frac{A_{d}-S_{1}}{S_{2}-S_{1}}
$$

$A_{d}$ : 試験片の垂直投影面積（ドレープ形状面積, $\mathrm{mm}^{2}$ )

$$
S_{1} \text { : 試料台の面積 }\left(\mathrm{mm}^{2}\right)
$$

$S_{2}$ : 試料の面積 $\left(\mathrm{mm}^{2}\right)$

13）曲げ反発性：L 1085 の剛軟度（ガーレ法）

14）防しわ率：L 1085 の防しわ率の A 法（針金 法）とB法（モサント法）による.ただし, 試験片 はたて，よこ方向にそれぞれ10枚ずつ採取し，5枚 は表と表を, 残りの 5 枚は裏と裏を接するように,
長辺を直角に二つ折りとして試験し，10回の平均値 を整数位まで求める.

又，試験の状態は次のように規定する。

標準状態時 $\left\{\begin{array}{l}\text { 前処理をしない状態 } \\ \text { 洗剂夜で処理した状態(1) }\end{array}\right.$

湿潤状態時 $\left\{\begin{array}{l}\text { 過㮃水分を除去した状態(2) } \\ \text { 過㮃水分を除去しない状態 }\end{array}\right.$

注(1)：試験片を JIS K 3302 （固形洗濯石䍄）規定 の無添加剂 ( 1 種) の石畭 $0.5 \%$ を含む $50 \pm 1{ }^{\circ} \mathrm{C}$ の 溶液 (浴比50：1) 中で20分間操作後, $50 \pm 1{ }^{\circ} \mathrm{C}$ の 水で20分間水洗, 脱水, 風乾して標準状態としたも の.

(2)：試験片を $0.2 \%$ の非イオン界面活性剤と0.2\% の無水炭酸ナトリウムを含む $40^{\circ} \mathrm{C}$ の溶液に 15 分間 浸漬させた後, 水洗し濾紙で過剩水分を取り除いた あので，直ちに湿潤したままの状態で試験する.

(3)：前項(2)の条件の溶液に15分間浸漬させた後, 水洗し試験片を直角に二つ折りとし，水を入れたバ ットの中で測定法に準じて荷重を加えた後取り出 し，そのまま濡れた状態で試験する.

15）染色堅牢度 : 而光堅牢度（JIS L 0841 又は L 08421), 洗濯堅审度 (JIS L 0844), 熱湯堅审度（JIS L 0845), 汗堅牢度（JIS L 0848）, 摩擦堅牢度（JIS L 0849), ホットプレッシシグ堅牢度 (JIS L 0850), 塩素漂白堅牢度 (JIS L 0856), ドライクリーニング 堅审度（JIS L 0860）による.

16）塩素漂白及びスコーチングに対する変色度： 試料から $2.5 \mathrm{~cm} \times 1.5 \mathrm{~cm}$ の試験片を採取し, JIS L 0856 (塩素漂白に対する染色堅牢度試験方法) の 3 の(2)の試験液 $B$ を用いて 7 の操作を行う. 次にあら かじめ $185 \pm 1{ }^{\circ} \mathrm{C}$ に加熱調整されたスコーチテス ター（JIS L 0879, 乾熱好理に対する染色堅牢度試 験法の 4 の(1))を用いて, 図 $7 \cdot 12$ のように中央部全 幅がスコーチされるように，熱板と直角に試験片を 置き $30 \mathrm{sec}$ 間プレスする. ただし，白生地の場合で スコーチをかけた部分の判定は JIS L 0801（染色堅 牢度試験方法通則）の10に準じて表 $7 \cdot 2$ の判定基 準により行う。

17）遊離ホルムアルデヒド量：試験は JIS L 1041 （樹脂加工織物及び編物の試験方法）の $5 \cdot 2$ の（1 -2）アセチルアセトン法による.

18）収縮率：試験は JIS L 1018 （メリヤス生地試 験方法）の $6 \cdot 36$, JIS L 1042 (織物の収縮率試験方 法）又はJIS L 1057 (織物及び編物のアイロン収縮 
表 $7 \cdot 2$ 染色堅牢度試験法

\begin{tabular}{|c|c|c|c|}
\hline 等級(級) & 半川 & 定 & 準 \\
\hline 1 & \multicolumn{3}{|c|}{ 色の変化が変退色用グレースケールの 1 号又はその程度を超えるもの } \\
\hline $1-2$ & \multicolumn{3}{|c|}{ 色の変化が変退色用グレースケールの $1-2$ 号程度のもの } \\
\hline 2 & \multicolumn{3}{|c|}{ 色の変化が変退色用グレースケールの 2 号程度のもの } \\
\hline $2-3$ & \multicolumn{3}{|c|}{ 色の変化が変退色用グレースケールの $2-3$ 号程度のもの } \\
\hline 3 & \multicolumn{3}{|c|}{ 色の変化が変退色用グレースケールの 3 号程度のもの } \\
\hline $3-4$ & \multicolumn{3}{|c|}{ 色の変化が変退色用グレースケールの $3-4$ 号程度のもの } \\
\hline 4 & \multicolumn{3}{|c|}{ 色の変化が変退色用グレースケールの 4 号程度のもの } \\
\hline $4-5$ & \multicolumn{3}{|c|}{ 色の変化が変退色用グレースケールの $4-5$ 号程度のもの } \\
\hline 5 & \multicolumn{3}{|c|}{ 色の変化が変退色用グレースケールの 5 号程度のもの } \\
\hline
\end{tabular}

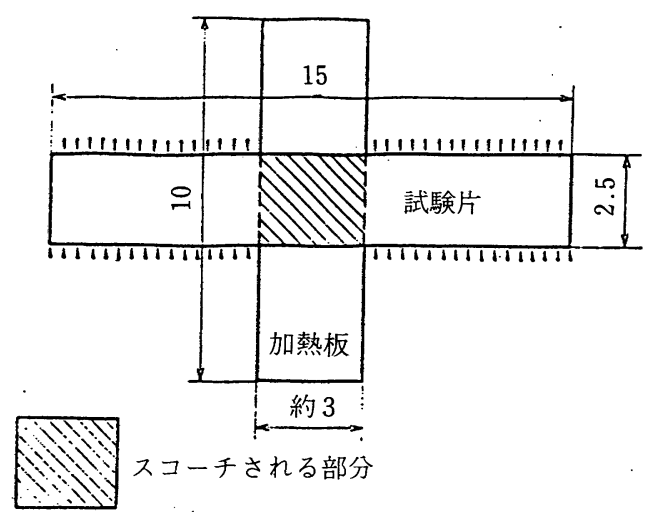

図 $7 \cdot 12$ スコーチテスターと試験片（単位 $\mathrm{cm}$ )

率試験方法）による．ただし，プレス収縮率及びア イロン収縮率は前述の複合試験法にだけ適用する.

19）剝離強さ：標準状態時の前処理をしない状態 の基準には, 複合試験片の作り方によって $2.5 \mathrm{~cm} \times$ $15 \mathrm{~cm}$ の試験片を被接着布のたて，よこ方向にそれ ぞれ 5 枚以上採取し, 長辺の方向に辺から約 $5 \mathrm{~cm}$ を剝離し，自記装置付き引っ張り試験機を用い，試

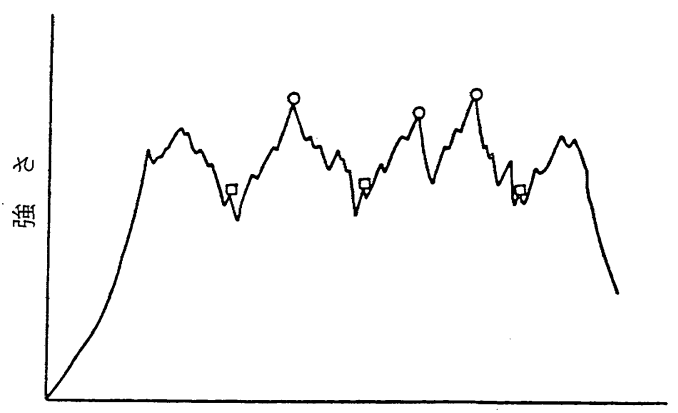

○印 : 極大値の大きいものから 3 個

$\square$ 印：極大值の小さいものから 3 個

図 $7 \cdot 13$ 剶離強さ
験片のつかみ間隔 $5 \mathrm{~cm}$, 引っ張り速度 1 分当たり $10 \mathrm{~cm}$ として $5 \mathrm{~cm}$ 間を剝離して, 図 $7 \cdot 13$ に見られ る破断曲線から極大值 (gf) $\{\mathrm{N}\}$ の大きいむのから 順次 3 個, 小さなものから順次 3 個をとり, 計 6 個 の平均値を算出し，たて，よこ方向それぞれ 5 回以 上の平均值を整数位まで求める．標準状態時の前処 理をした基準では複合試験片の大きさは $\mathrm{A}$ 法では 約 $45 \mathrm{~cm} \times 45 \mathrm{~cm}$, B 法では約 $25 \mathrm{~cm} \times 25 \mathrm{~cm}$ でそ れぞれ必要枚数を採取し，処理中に布端からほつれ や剝れがないように試験片の周囲をオーバロック縫 いした後, 次の A 法, B 法のいずれかの方法で処理 したものについて，前述と同様な方法で剝離強さを 求める. A 法は JIS L 0217 (繊維製品の取扱いに関 する表示記号及びその表示法の別表, 記号別の試験 方法の(1)洗い方に規定する方法のいずれかによる.

B 法は JIS L 1018 の 6 36·2の E- 2 法により処 理し, $6 \cdot 36 \cdot 3$ により脱液, 乾燥する.

処理液はパークロロエチレン（JIS L 1521）1lに 対し陰イオン界面活性剂（JIS L 0860） $10 \mathrm{~g}$ 及び非 イオン界面活性剤（前同） $10 \mathrm{~g}$ を溶かし水 $1 \mathrm{ml}$ を 加えて均一透明にした液とする.

20）水洗い又はドライクリーニング後の外観変 化：複合試験片の作り方によって, A 法では約 45 $\mathrm{cm} \times 45 \mathrm{~cm}, \mathrm{~B}$ 法では約 $25 \mathrm{~cm} \times 25 \mathrm{~cm}$ の試験片 をそれぞれ 2 枚採取し周囲を縫い合わせ次のいずれ かの方法 (A，B法)により処理した後, アイロン仕 上げを行ったものについて，表 $7 \cdot 3$ に従って区分 し欠点事項を付記する. A 法と B 法の処理条件は 19）之同様に行う.

アイロン仕上げは JIS L 0217 に規定する. [参考]接着時のプレス収縮率又はアイロン収縮率

A 法：JIS L $1042 （$ 織物の収縮率試験方法）の 8 ・ 3 のプレス収縮率又は JIS L 1057 （織物及び編物の 
表 7·3 外観測定

\begin{tabular}{c|c}
\hline \hline 区分 & \multicolumn{1}{|c}{ 試験片の状態 } \\
\hline 1 & 全面や部分鶨離のあるあの又は外観変化, \\
& 風合い変化が甚しく目立つあの \\
2 & 外観変化, 風合い変化がやや目立つあの \\
3 & 外観変化, 風合い変化が目立たないあの \\
\hline
\end{tabular}

外観変化とは, しみ出し・弯曲・接着剤移りや当たりの状 態をいう。

アイロン収縮率試験方法）に規定する方法のいずれ かによって, 芯地の裏面に接着剤のこて面融着を防 止し，収縮性能に影響の少ない紙等を重ね合わせた 状態で行う。

$\mathrm{B}$ 法：前述の JIS に規定する方法のいずれかによ って, 芯地の裏面に被接着布を重ねた状態で試験を 行う.

\section{3 靴甲用人工皮革試験方法}

（1）適用範囲
この規格は靴の甲材料に使用する人工皮革の試験 方法について規定する.

\section{（2）用語の意味}

靴甲用人工皮革とは高分子物質を繊維層に浸透さ せ革の組織構造に準拠して作られたもので，高分子 物質は連続微細多孔構造を持ち織維層にランダム三 次元立体構造をもつ靴の甲材をいう。

\section{（3）試験の一般条件}

1 ）試験片の標準状態：JIS Z 8703 (試験場所の 標準状態) の標準温湿度状態 1 類 (温度 $20 \pm 1{ }^{\circ} \mathrm{C}$, 相対湿度 $65 \pm 2 \%$ ）中に 24 時間放置し，水分が平 衡に達した状態をいう.

2 ）試験室の標準状態：JIS Z 8703 の標準温度状 態 3 類 $\left(20 \pm 5{ }^{\circ} \mathrm{C}\right)$ 及び相対温度 $65 \pm 10 \%$ とす る.

\section{（4）試験の項目, 片数, 值の位数}

この規格に規定する試験項目, 試験片数及び求め る試験值の位数は表 $7 \cdot 4$ のとおりとする. 求める

表 $7 \cdot 4$ 靴甲用人工皮革試験

\begin{tabular}{|c|c|c|c|c|}
\hline 試 験 項 目 & 単 位 & 試験片数 & 測 定 值 & 求める数值の位数 \\
\hline & $\mathrm{mm}$ & $3^{(1)}$ & 小数点以下 2 けた & 小数点以下 1 けた \\
\hline & $\mathrm{mg} / \mathrm{cm}^{2}$ & 2 & 小数点以下 1 けた & 整 数 位 \\
\hline 見掛密度 & $\mathrm{g} / \mathrm{cm}^{3}$ & 2 & 小数点以下 3 けた & 小数点以下 2 けた \\
\hline 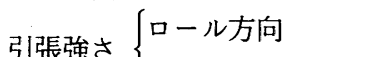 & $\mathrm{kg} / \mathrm{mm}^{2}$ & 3 & 小数点以下 3 けた & 小数点以下 2 けた \\
\hline$\{$ ロールに垂直方向 & $\mathrm{kg} / \mathrm{mm}^{2}$ & 3 & 小数点以下 3 けた & 小数点以下 2 けた \\
\hline \{ロール方向 & $\%$ & $3^{(2)}$ & 小数点以下 1 けた & 整 数 位 \\
\hline |ロールに垂直方向 & $\%$ & $3^{(2)}$ & 小数点以下 1 けた & 整 数 位 \\
\hline 引㤠胎さ\{ロール方向 & $\mathrm{kg} / \mathrm{mm}$ & 3 & 小数点以下 2 けた & 小数点以下 1 けた \\
\hline 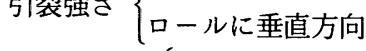 & $\mathrm{kg} / \mathrm{mm}$ & 3 & 小数点以下 2 けた & 小数点以下 1 けた \\
\hline 耐屈曲性 ${ }^{(3)} \begin{cases}\text { 常 } & \text { 温 } \\
\text { 低 } & \text { 温 }\end{cases}$ & & $\begin{array}{l}2 \\
2\end{array}$ & & \\
\hline 耐熱粘着性 & & 1 & & \\
\hline 表面摩耗強さ & & 2 & & \\
\hline 表面われ 荷 重 & $\mathrm{kg}$ & 3 & 小数点以下 1 けた & 整 数 位 \\
\hline 表面われ $\{$ 高 & $\mathrm{mm}$ & $3^{(4)}$ & 小数点以下 1 けた & 小数点以下 1 けた \\
\hline 半球状可塑性 & $\%$ & 3 & 小数点以下 1 けた & 整 数 位 \\
\hline 耐 水 度 & $\min$ & 2 & 小数点以下 1 けた & 整数 位 \\
\hline 吸水度 & $\%$ & 2 & 小数点以下 1 けた & 整 数 位 \\
\hline 吸湿度 & $\mathrm{mg} / \mathrm{cm}^{2}$ & 2 & 小数点以下 2 けた & 小数点以下 1 けた \\
\hline 透湿度 & $\mathrm{mg} / \mathrm{cm}^{2} \mathrm{hr}$ & 2 & 小数点以下 2 けた & 小数点以下 1 けた \\
\hline 染色摩擦堅ろう度 $\begin{cases}\mathrm{A} & \text { 法 } \\
\mathrm{B} & \text { 法 }\end{cases}$ & & $\begin{array}{l}1 \\
1\end{array}$ & & \\
\hline
\end{tabular}

注（1）表面われ試験片を用いて測定する.

（2）引っ張り強さと同じ試験片を用いる.

（3）試験片はロール方向に平行に採取する.

（4）荷重と同じ試験片を用いる. 
試験値の数值の丸め方は JIS Z 8401 による.

\section{(5) 試験方法}

1 ）試験片の採取方法：試験片はロール端末から $50 \mathrm{~cm}$, 両側端から $5 \mathrm{~cm}$ を除いた部分から無作為 に採取する。

2) 操作

(a) 厚さ：次によって測定する

。測定器は $1 / 100 \mathrm{~mm}$ の目盛をもち加圧面は平 滑な直径 $10 \pm 0.1 \mathrm{~mm}$ の円形，その圧荷重は 393 $\pm 10 \mathrm{~g}$ とする. ただし, 加圧面の直径が $5 \sim 10$ $\mathrm{mm}$, 圧荷重 $500 \pm 129 \mathrm{~g} / \mathrm{cm}^{2}$ の測定器を使用して あよい.

○測定個所はその中心とその円周の直径から約 5 $\mathrm{mm}$ 小なる同心円上の組間隔な 4 か所の計 5 か所 とする.

。厚さの測定は試料の表面を上にして測定器の下 部台上に置き，加圧面を静かに試料の上に置いて加 圧し， $5 \mathrm{sec}$ 経過してから $0.01 \mathrm{~mm}$ まで測定する.

。厚さは 3 個の試験片のそれぞれの 5 か所の計 15 か所の平均值とする.

(b) 重さ及び見掛け密度 : 試験片の厚さ, 直径及 び重さから次の式によって重さ及び見掛け密度を算 出する.

$$
\begin{aligned}
& W=\frac{W_{1}}{0.785 d^{2}}\left(\mathrm{mg} / \mathrm{cm}^{2}\right) \\
& A D=\frac{W}{100 t}\left(\mathrm{~g} / \mathrm{cm}^{2}\right)
\end{aligned}
$$

ここに $W$ : 重さ, $W_{1}$ : 試験片の重さ $(\mathrm{mg}), d:$ 試 験片の直径 $(\mathrm{cm}), A D$ : 見掛け密度, $t$ : 試験片の 厚さ $(\mathrm{mm})$ (c) 引っ張り強さ及び伸び率：JIS K 6550 (革の 試験方法）の $5 \cdot 1$ によって試験する. ただし, 試験 片はつかみ部分を $20 \mathrm{~mm}$ ずつ固定し，つかみ部分 の間隔が正確に $50 \mathrm{~mm}$ となるように取り付ける. 引っ張り強さ及び伸び率はロール方向に平行及び垂 直のそれぞれの平均值を算出する．ただし，伸びは つかみ間隔で測定する。

(d) 引き裂き強さ：JIS K 6550 のように $5 \cdot 2$ に よって試験しロール方向に平行及び垂直のそれぞれ の平均值を算出する。

（e）耐屈曲性：試験条件によって常温試験及び低 温試験に区分し，それぞれ JIS K 6545 (革の耐屈曲 性試験方向）の 5 の装置を使用し $6 \cdot 1 \sim 6 \cdot 3$ の方 法によって試験し，表と裏両面より損傷を検査し表 $7 \cdot 5$ の基準によって図 $7 \cdot 14$ を参考にして判定す る.

○常温試験：標準状態によって調整した $70 \mathrm{~mm}$ $\times 40 \mathrm{~mm}$ の長四角形の試験片を試験室の標準状態 によって調整された室内で $10,000 ， 30,000$, 100,000 及び 20,000 回屈曲後, それぞれ判定する.

。低温試験：標準状態によって調整した試験片を 温度- $10 \pm 3{ }^{\circ} \mathrm{C}$ 中に 30 分間放置後, 同温度で試験 を行い，5,000，10,000及び 25,000 回屈曲後それぞ れ判定する.

(f) 耐熱粘着性： $(60 \pm 1 \mathrm{~mm}) \times(90 \pm 1 \mathrm{~mm})$ の 2 枚の試験片の表面を向かい合わせ, $(60 \pm 1$ $\mathrm{mm}) \times(60 \pm 1 \mathrm{~mm})$ の平滑なガラス板 2 枚の間

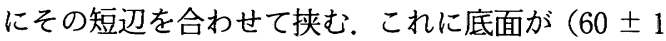
$\mathrm{mm}) \times(60 \pm 1 \mathrm{~mm})$, 重さ $3 \mathrm{~kg}$ のおありを載せ $100 \pm 2{ }^{\circ} \mathrm{C}$ の空気恒温器中に 1 時間放置した後, 取

\begin{tabular}{|c|c|c|c|}
\hline 区分 & 等級 & 表 & 裏 \\
\hline \multirow{5}{*}{$\begin{array}{l}\text { ス } \\
厶 \\
1 \\
\text { ス }\end{array}$} & 1 & 部分的に切断を生じたもの & 部分的に切断を生じたもの \\
\hline & 2 & 不織布又は織布層に亀裂を生じたもの & 連続微細多孔層に亀裂を生じたもの \\
\hline & 3 & 表面仕上層をこええて亀裂を生じたもの & 織布又は不織布層に亀裂を生じたもの \\
\hline & 4 & わずかに亀裂が認められるあの & わずかに異常が認められるもの ‘ \\
\hline & 5 & 亀裂の認められないもの & 異常の認められないもの \\
\hline \multirow[b]{2}{*}{ ナ } & 1 & 部分的に切断を生じたもの & 部分的に切断を生じたすの \\
\hline & 2 & $\begin{array}{l}\text { 表面（毛羽状）層をこえて織布又は不 } \\
\text { 織布層に亀裂を生じたもの }\end{array}$ & $\begin{array}{l}\text { 織布又は不織布層と表面（毛羽状）層 } \\
\text { との界面に達する亀裂を生じたもの }\end{array}$ \\
\hline ッ & 3 & 表面（毛羽状）層と織布又は不織布層 & 織布又は不織布層に亀裂を生じたもの \\
\hline \multirow[t]{2}{*}{$フ^{\circ}$} & 4 & $\begin{array}{l}\text { との界面に達する电裂を生じたもの } \\
\text { わずかに異常の認められるすの }\end{array}$ & わずかに異常の認められるあの \\
\hline & 5 & 異常の認められないむの & 異常の認められないもの \\
\hline
\end{tabular}

表 $7 \cdot 5$ 判定基準 

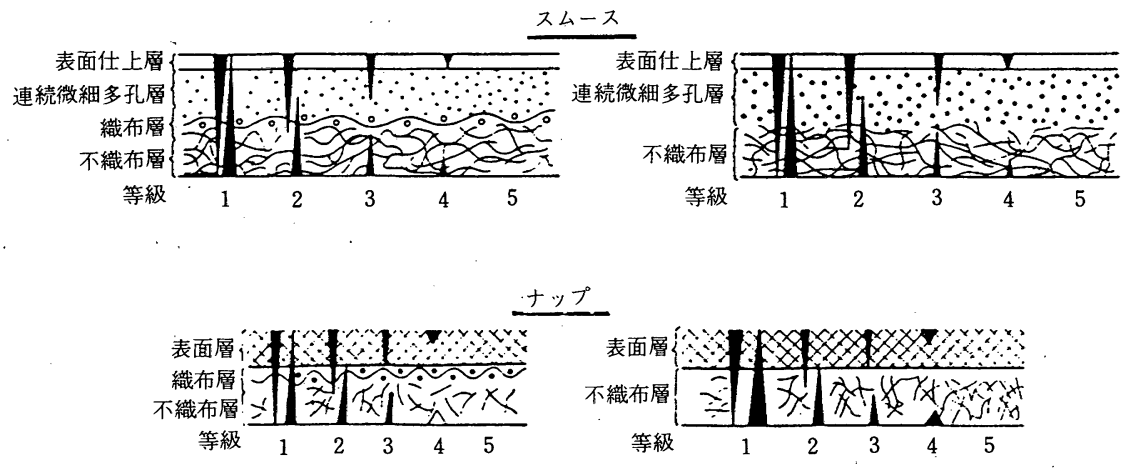

図 $7 \cdot 14$ 人工皮革の構造の判定基準

出しておすりを除き標準状態によって調整された室 内に 1 時間放置した後， 2 枚の試験片を静かに㔀が し表面の損傷 (異常) の有無を検查し表 $7 \cdot 6$ の基準 によって判定する.

（g）表面摩耗強さ：JIS L 1079 (化学繊維織物試 験法） $5 \cdot 16$ の $A$ 法の(a) (平面摩耗強さ) による.

ただし，試験は表面を上方にして取り付ける.

試験にはJIS R 6253 (耐水研摩耗紙) のCwCC 400 を使用し，125，250，500及び1,000回の摩耗の 後, 損傷の有無を検查し表 $7 \cdot 7$ の基準によって判 定する:

（h）表面われ：JIS K 6548 （革の銀面われ試験方 法）によって試験する.

(i) 半球状可塑性：JIS K 6546（革の半球状可塑 性試験方法）によって試験する。だだし，成形温度 は $100 \pm 2{ }^{\circ} \mathrm{C}$, 成形加熱時間は $30 \pm 1$ 分とする。

(j) 而水度：JIS K 6550 の $5 \cdot 3$ により試験する.

(k) 吸水度 : JIS K 6550 の $5 \cdot 4$ により試験する.

表 7.6 判定基準

\begin{tabular}{|c|c|c|c|c|}
\hline 区分 & 等級 & 判 & 定 & 準 \\
\hline $\begin{array}{l}x \\
\Delta \\
1 \\
x\end{array}$ & $\begin{array}{l}1 \\
2 \\
3 \\
4 \\
5\end{array}$ & \multicolumn{3}{|c|}{$\begin{array}{l}\text { 表面仕上層をこえた損傷の認められるもの } \\
\text { 表面仕上層の損傷が認められるもの } \\
\text { 光沢及び表面形状が変化するあの } \\
\text { 光沢及び表面形状がわずかに変化するむの } \\
\text { 外観上変化が認められないすの }\end{array}$} \\
\hline プ & $\begin{array}{l}1 \\
2 \\
3 \\
4 \\
5\end{array}$ & \multicolumn{3}{|c|}{$\begin{array}{l}\text { 表面(毛羽状)層をこえた損傷の認められ } \\
\text { るあの } \\
\text { 表面(毛羽状)層の大部分が損傷するむの } \\
\text { 表面(毛羽状)層の二部が損傷するもの } \\
\text { わずかに異常の認められるあの } \\
\text { 外観上変化が認められないあの }\end{array}$} \\
\hline
\end{tabular}

表 $7 \cdot 7$ 判定基準

\begin{tabular}{|c|c|c|c|c|c|}
\hline 区分 & 等級 & 判 & 定 & 基 & 準 \\
\hline & 1 & \multicolumn{4}{|c|}{ 貫通孔を生じたあの } \\
\hline z & 2 & \multicolumn{4}{|c|}{ 不織布又は織布層の露出が著しいもの } \\
\hline$\Delta$ & 3 & \multicolumn{4}{|c|}{ 表面仕上層が全く消滅し，微細多孔層の } \\
\hline 1 & & \multicolumn{4}{|c|}{ 大部分が露出じたもの } \\
\hline ス & 4. & \multicolumn{4}{|c|}{ 着色表面仕上層の一部が消滅したもの } \\
\hline & 5 & \multicolumn{4}{|c|}{ 外観上変化が認められないもの } \\
\hline & 1 & \multicolumn{4}{|c|}{ 貫通孔を生じたもの } \\
\hline ナ & 2 & \multirow{2}{*}{\multicolumn{4}{|c|}{$\begin{array}{l}\text { 表面(毛羽状)層をこえて不織布又は織布 } \\
\text { 層の一部が破壊されたもの }\end{array}$}} \\
\hline " & & & & & \\
\hline J & 3 & \multicolumn{4}{|c|}{ 表面(毛羽状)層の大部分が消隇したもの } \\
\hline プ & 4 & \multicolumn{4}{|c|}{ 表面(毛羽状)層の一部が消滅したもの } \\
\hline & 5 & \multicolumn{4}{|c|}{ 外観上変化が認められないもの } \\
\hline
\end{tabular}

(1) 吸湿度：JIS K 6544 (革の吸湿度試験方法) によって試験する，ただし，試験片の調整及び時間 並びに試験室の調整は $3 \cdot 1$ 及び $3 \cdot 2$ による.

(m) 透湿度：JIS K 6549 (革の透湿度試験方法) によって試験する.

(n) 染色廉擦堅牢度 : 次のいずれかの方法によっ て試験する。

A 法：JIS K 6547 (革の染色摩擦堅牢試験方法) によって試験する.

B 法：JIS L 0849 （摩擦に対する染色堅牢度試験 方法）の $4 \cdot 1$ に規定の学振型摩擦堅牢度試験機を 用い $6 \cdot 1$ によって試験する.

[参考〕関連規格として靴甲用人工皮革 (JIS K 6601）がある. この規格の適用範囲は男子靴（成年 男子が一般歩行に用いるすの）及び婦人，子供靴の 甲部に使用する人工皮革について規定する.ここで いう子供靴とはJIS S 5029 (皮靴の標準呼び寸法) 
表 $7 \cdot 8$ スムースとナップの規格

\begin{tabular}{|c|c|c|c|c|c|c|c|}
\hline \multirow{2}{*}{\multicolumn{2}{|c|}{ 試験項目（単位） }} & \multirow{2}{*}{\multicolumn{2}{|c|}{ 種 類 }} & \multicolumn{2}{|c|}{ スムース } & \multicolumn{2}{|c|}{$ナ ッ \quad フ^{\circ}$} \\
\hline & & & & \multirow{2}{*}{$\begin{array}{l}\text { 男子用 } \\
1.2 \text { 以上 }\end{array}$} & \multirow{2}{*}{$\frac{\text { 婦人 ·子供用 }}{0.8 \text { 以上 }}$} & \multirow{2}{*}{$\frac{\text { 男子用 }}{1.2 \text { 以上 }}$} & \multirow{2}{*}{$\frac{\text { 婦人・子供用 }}{0.8 \text { 以上 }}$} \\
\hline 厚 & さ $(\mathrm{mm})$ & & & & & & \\
\hline \multicolumn{4}{|c|}{ 見掛密度 $\quad\left(\mathrm{g} / \mathrm{cm}^{3}\right)$} & 0.80 以下 & 0.80 以下 & 0.80 以下 & 0.80 以下 \\
\hline \multirow{4}{*}{$\begin{array}{c}\text { 引っ張り強さ } \\
(\mathrm{kg} / \mathrm{cm})\end{array}$} & \multirow{2}{*}{$\begin{array}{l}\text { 伸びが30\% } \\
\text { 未満のもの }\end{array}$} & \multicolumn{2}{|l|}{ ロール方向 } & \multirow{2}{*}{10 以上 } & \multirow{2}{*}{7 以上 } & \multirow{2}{*}{10 以上 } & \multirow{2}{*}{7 以上 } \\
\hline & & \multicolumn{2}{|c|}{ ロールに直角方向 } & & & & \\
\hline & \multirow{2}{*}{$\begin{array}{l}\text { 伸びが } 30 \% \\
\text { 以上のもの }\end{array}$} & \multicolumn{2}{|l|}{ ロール方向 } & \multirow{2}{*}{7 以上 } & \multirow{2}{*}{4 以上 } & \multirow{2}{*}{7 以上 } & \multirow{2}{*}{4 以上 } \\
\hline & & \multicolumn{2}{|c|}{ ロールに直角方向 } & & & & \\
\hline \multirow{2}{*}{ 伸 } & \multirow{2}{*}{ び (\%) } & \multicolumn{2}{|l|}{ ロール方向 } & \multirow{2}{*}{15 以上 } & \multirow{2}{*}{15 以上 } & \multirow{2}{*}{15 以上 } & \multirow{2}{*}{15 以上 } \\
\hline & & \multicolumn{2}{|c|}{ ロールに直角方向 } & & & & \\
\hline \multirow{2}{*}{\multicolumn{2}{|c|}{ 引き裂き強さ （kg） }} & ロール方向 & & & & & \\
\hline & & ロールに直 & 百方向 & 2.0 & 1.0 2 & 2.0 & $1.0 \mathrm{X} 工$. \\
\hline & 常 温 & 10 万 & & 4 以上 & 4 以上 & 4 以上 & 4 以上 \\
\hline 耐屈曲性 & $\left(20^{\circ} \mathrm{C}\right)$ & 20 万 & & 3 以上 & 3 以上 & 3 以上 & 3 以上 \\
\hline （級） & 低 温 & $5 千$ & & 4 以上 & 4 以上 & 4 以上 & 4 以上 \\
\hline & $\left(-10^{\circ} \mathrm{C}\right)$ & 2 万 $5 千$ & & 3 以上 & 3 以上 & 3 以上 & 3 以上 \\
\hline 耐䒧 & 粘着性 （級） & & & 4 以上 $^{(1)}$ & 4 以上 ${ }^{(1)}$ & 3 以上 & 3 以上 \\
\hline 表面わわ討駩 & 表面われ又は & 常時の高さ & $(\mathrm{mm})$ & 7.0 以上 & 7.0 以上 & 7.0 以上 & 7.0 以上 \\
\hline 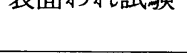 & $7.0 \mathrm{~mm}$ 高さ耺 & 刀荷重 （kg） & & $5 \sim 17$ & $4 \sim 16$ & $4 \sim 15$ & $3 \sim 14$ \\
\hline & 状可塑性 （9 & & & 30 以上 & 30 以上 & 20 以上 & 20 以上 \\
\hline 耐 & 水度 $150 \mathrm{~cm}$ & 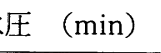 & & 1 以上 & 1 以上 & - & - \\
\hline 吸 & 水 度 24 時間 & $(\%)$ & & 15 以上 & 15 以上 & 15 以上 & 15 以上 \\
\hline & 显度 $(\mathrm{mg} / \mathrm{c}$ & ²hr) & & 1.5 以上 $^{(2)}$ & 1.5 以上 & 4.0 以上 & 4.0 以上 \\
\hline & 糜擦堅暒度 & 4) & 乾 & 4 以上 & 4 以上 & 3 以上 & 3 以上 \\
\hline & & & 湿 & 3 以上 & 3 以上 & 2 以上 & 2 以上 \\
\hline
\end{tabular}

注 (1)：エナメル仕上げの場合は，3以上とする.

(2)：エナメル仕上げの場合は，この規定を除く.

(3)：試験片の銀面を上にして平らな台上に置き，その上に JIS R 6252（研摩紙）の CC180 番の研摩紙の研摩面を下にして重 ねる．試験片に約 $200 \mathrm{~g}$ の荷重か均一にかかるようにして，方向を变えてバフしたのち測定する。

(4)：評価はJIS K 6547 (革の染色摩擦堅军度試験方法）により行い，変退色，污染ともにこの規定による.

に規定する子供靴のサイズ（182/1～2）及び合サイ ズ $(211 / 2 \sim 231 / 2):$ の靴と規定する. 又，スムース とは革の銀面様の外観を有するすの,ナップとは靴 のスエード，ベロア等の外観を有するものと定めて いる.

品質は前述の「靴甲用人工皮革試験方法」によっ
て試験し，表 $7 \cdot 8$ の規定に適合しなければならな いと定めている。

\section{文献}

1）三浦義人；不織布要論，267，高分子刊行会（1973）

2）土林貞夫；最新不織布技術之応用展開， 352 , 工学研究セン 夕- (1989) 